Linköping Studies in Science and Technology

Thesis No. 1795

\title{
Domestication and early experiences in chickens \\ Behavior, stress and gene expression
}

Pia Katrine Løtvedt

\author{
IFM Biology \\ Department of Physics, Chemistry and Biology \\ Linköping University, \\ SE-581 83, Linköping, Sweden
}


Domestication and early experiences in chickens: Behavior, stress and gene expression Pia Katrine Løtvedt

Linköping Studies in Science and Technology, Thesis No. 1795

ISBN: 978-91-7685-392-4

ISSN: 0280-7971

Copyright Pia Katrine Løtvedt

Printed by LiU-Tryck, Linköping, Sweden, 2017 




\begin{abstract}
A number of animal species have undergone domestication, the process of becoming adapted to living in captivity and in proximity to humans. Common for these species is that they have all developed certain traits, including changes to coat color, body size and level of fearfulness. This has been termed the domestic phenotype. Among these traits is also an attenuation of the response to stress, both behaviorally and physiologically. Thus, release of glucocorticoids such as cortisol or corticosterone is lower in domesticated species. However, the underlying mechanism for this is not yet well understood. In this thesis, we have investigated genetic mechanisms for the attenuation of the physiological stress response in ancestral chickens, the Red Junglefowl, and domesticated chickens, the White Leghorn.
\end{abstract}

We found a number of genes that differed in expression between the two breeds in several tissues involved in the stress response. Among the most interesting findings were lower expression of genes involved in production and secretion of ACTH in the pituitary, and in the production of glucocorticoids in the adrenal glands, in the domesticated White Leghorns. We also found higher expression of the glucocorticoid receptor in White Leghorns, indicating that they may have a more efficient negative feedback of the physiological stress response.

We then investigated the transcriptome of the chicken pituitary more closely, and we discovered that a number of genes highly involved in several important physiological axes showed differential expression between the ancestral and the domesticated breed. Among these were genes involved in the stress response, the reproductive system, and in metabolism and growth. As these traits are modified in domesticated species, our results suggest that changes to gene expression in the pituitary may be an important underlying factor of the domestic phenotype.

A separate aim of this thesis was to investigate effects of hatching time in chickens on their subsequent phenotype. Time of hatching constitutes an early experience that may differ between individuals, and we therefore hypothesized that differences in hatching time would affect chickens later in life. While a number of studies have been performed on hatching time and post-hatch growth, very little work has been done on effects on behavior. We found that the time of hatching had sex-specific effects. Hatching times in females were negatively correlated with body weight, whereas in males, behaviors such as reaction to novelty and spatial learning were affected.

As time of hatching is governed by various hormones, including thyroid hormone and corticosterone, we suggest that changes to the levels of these hormones could affect both hatching time and post-hatch phenotypes. Understanding these mechanisms better would be beneficial in terms of production, where batch homogeneity is important, in research on early experiences and the potential for maternal programming, and in evolutionary questions on trade-off between different life strategies. 


\section{Populärvetenskaplig sammanfattning}

Processen där djur anpassas till att leva i fångenskap och i närhet till människor kallas för domesticering. Många djurarter har blivit domesticerade; exempel på dessa är hunden, hästen, fåret, grisen och hönan.

Domesticeringen av höns började i östra Asien för 8000 år sedan. Röd djungelhöna, förfadern till alla dagens domesticerade höns, lever fortfarande kvar där. Detta gör att vi kan jämföra ursprungshönan med domesticerade höns, som till exempel den äggläggande rasen White Leghorn, och lära oss mer om ändringarna som har skett under domesticeringen.

Om man jämför olika domesticerade djurarter visar det sig att de har utvecklat ett antal gemensamma drag, som till exempel ändringar i pälsfärg, kroppsstorlek, mindre rädsla för människor och ändringar i reproduktionsmönstret. Man har också observerat att domesticerade djur har en mindre utpräglad respons till stress, både vad gäller beteende och fysiologiskt, det vill säga, det som händer inuti kroppen. Mekanismerna som skapar skillnaden i stressrespons är dock inte väl förstådda.

När en individ utsätts för stress utsöndras stresshormonet kortisol hos däggdjur, eller hos fåglar, kortikosteron. Detta händer som ett resultat av en kedja av hormonella reaktioner som kallas HPA-axeln (HPA står för hypothalamus-pituitary-adrenal). Hypothalamus är en del av hjärnan, och när individen utsätts för stress skickar hypothalamus hormoner till hypofysen. Hypofysen är en liten körtel som sitter precis under hjärnan. Hypofysens roll är att vidareförmedla signaler från hjärnan som handlar om bland annat stress, tillväxt och reproduktion, och den utsöndrar ett antal viktiga hormoner. När hypofysen får signaler om stress från hypothalamus utsöndrar den ett hormon som kallas ACTH. ACTH transporteras genom blodet till binjurarna, där det stimulerar produktion och utsläpp av kortikosteron.

Hos domesticerade höns har man tidigare mätt nivån av kortikosteron i blodet efter stress och sett att nivån är lägre än hos röda djungelhöns. I den här avhandlingen undersökte vi vilka gener som kan förklara denna skillnad genom att mäta nivån av genuttryck i olika vävnader involverade i den fysiologiska stressresponsen. Genuttrycket är det RNA som produceras från en särskild gen. RNA är kopior av genens DNA-sekvens, och antalet kopior som görs av en given gen kan variera mycket. RNA görs sedan om till proteiner som utför olika funktioner i kroppen. Man kan utgå ifrån att mängden av protein som skapas kommer att påverka hur effektivt den biologiska funktionen fungerar. Genom att mäta genuttryck, alltså mängden RNA, får man en indikation på hur mycket protein som skapas från en särskild gen. Om olika grupper av djur, till exempel djur från olika hönsraser, visar skillnader i genuttryck är det troligt att själva den biologiska funktionen också har påverkats.

Vi upptäckte att höns av den domesticerade rasen White Leghorn hade lägre uttryck av gener som är involverade i att producera kortikosteron i binjurarna. De hade också lägre uttryck av gener som producerar hormonen ACTH från hypofysen. Dessa resultat indikerar att den reducerade nivån av kortikosteron efter stress hos domesticerade höns är ett resultat av modifieringar i flera olika vävnader i kroppen.

På grund av hypofysens viktiga roll i flera funktioner i kroppen, bland annat de funktioner som ofta ändras av domesticeringsprocessen, bestämde vi oss sedan för att undersöka 
skillnader i genuttryck i hypofysen hos röda djungelhöns och White Leghorns på en större skala, vid att mäta uttryck av tusentals gener på en gång.

Vi upptäckte att det fanns tydliga skillnader på genuttryck i hypofysen hos djungelhöns och domesticerade höns. Bland generna vars uttryck skiljde sig fanns ett antal gener som är involverade i just de funktioner som har ändrats under domesticeringsprocessen. Våra resultat visar därför att domesticeringen kan ha påverkat djurarter genom att modifiera genuttryck i hypofysen.

Ett annat område som är av intresse inom forskningen är hur djurs erfarenheter tidigt i livet påverkar deras senare liv. Man vet från tidigare studier att djur som till exempel utsätts för stress under tiden före och efter födseln kan påverkas av detta senare i livet.

Hos fåglar kan man se kläckningsprocessen som en speciell form av tidig erfarenhet. Alla fåglar går igenom den, men det tar olika lång tid. Om man inkuberar ett antal ägg från höns samtidigt kan det ta upp emot 48 timmar från det att det första ägget kläcks till det sista kläcks. Den här skillnaden kan uppstå för att olika individer behöver olika lång tid $\mathrm{i}$ ägget för att bli redo för att kläckas, men också för att själva kläckningsprocessen tar kortare eller längre tid för olika kycklingar. Tidigare studier har visat att denna skillnad i kläckningstid hänger ihop med senare tillväxt hos kycklingarna, men väldigt lite forskning har undersökt om det finns någon effekt på beteende. Vi undersökte därför detta genom att göra ett antal olika beteendetest på kycklingar som hade kläckts efter olika lång tid.

Våra resultat visade att hos honor påverkades tillväxten, medan hos hanar påverkades beteendet. Hanar som hade kläckts tidigt visade en starkare reaktion till en ny miljö, vilket kan tyda på högre rädsla. De kunde också lösa ett inlärningsproblem fortare än hanar som kläcktes sent. Resultaten från det här försöket visar att det finns en koppling mellan tid för kläckning och senare tillväxt och beteende, men vi vet än så länge inte vilka mekanismer som skapar denna koppling. Vi föreslår att det kan vara hormoner som är involverade i både kläckningsprocessen och i att forma individens tillväxt och beteende senare i livet. Stresshormonet kortikosteron skulle kunna vara ett sådant hormon.

Som slutsats kan man säga att den här avhandlingen har ökat vår kunskap om domesticeringen och de mekanismer som har påverkat djur under domesticeringsprocessen. Vi har också fått en bättre förståelse för hur kläckningshändelsen hänger ihop med senare egenskaper hos höns. Resultaten från avhandlingen belyser därför två viktiga områden inom forskningen, men kan också vara till användning inom djurhållning, för att öka djurens välfärd. 


\section{List of publications}

I. Løtvedt, P.*, Fallahshahroudi, A.*, Bektic, L., Altimiras, J., \& Jensen, P. (2017). Chicken domestication changes expression of stress-related genes in brain, pituitary and adrenals. Neurobiology of Stress, 7, 113-121.

II. Fallahshahroudi, A.*, Løtvedt, P.*, Bèlteky, J., Altimiras, J., \& Jensen, P. Alterations in the gene expression pattern of the pituitary is consistent with domestication effects on the stress response in chickens. Manuscript

III. Løtvedt, P., \& Jensen, P. (2014). Effects of hatching time on behavior and weight development of chickens. PloS one, 9(7), e103040.

* Equal contribution 


\section{Table of Contents}

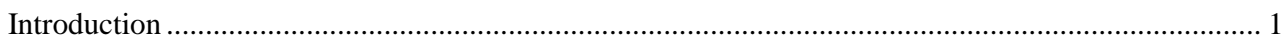

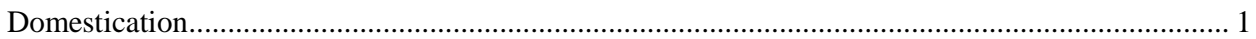

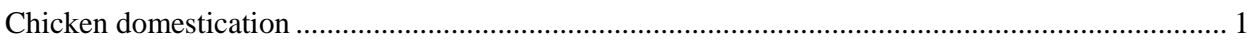

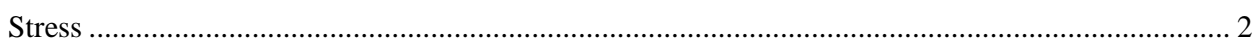

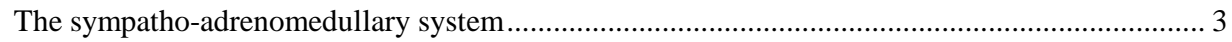

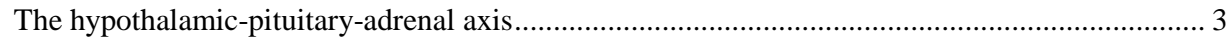

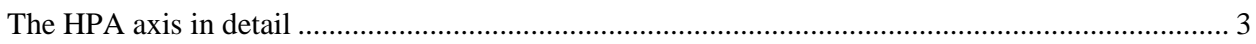

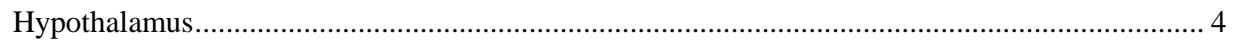

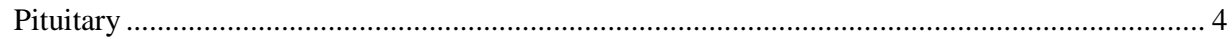

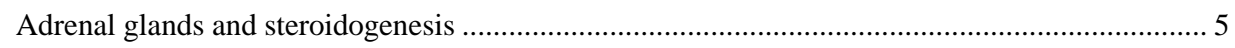

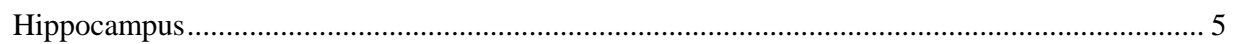

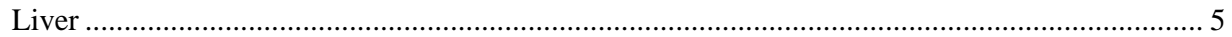

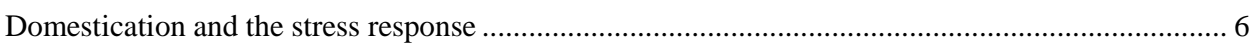

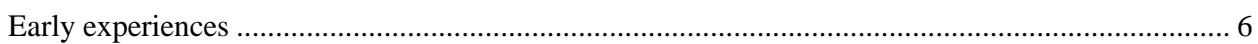

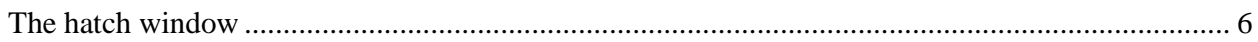

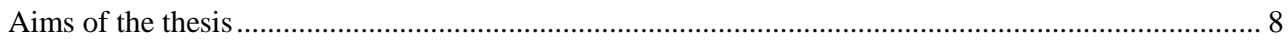

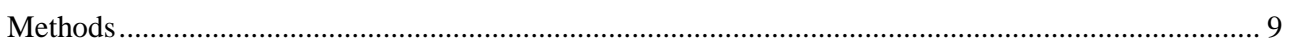

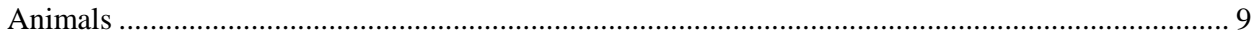

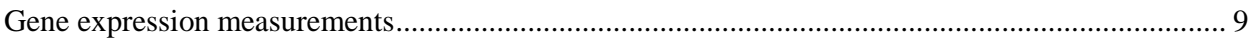

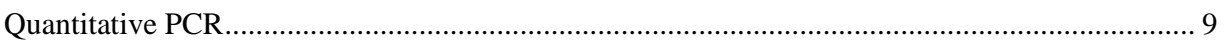

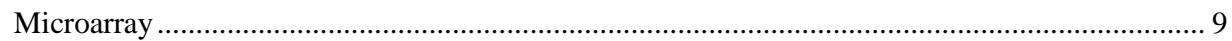

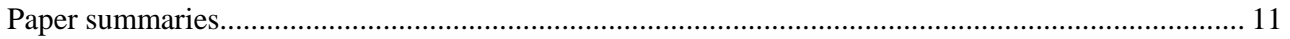

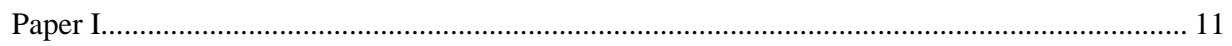

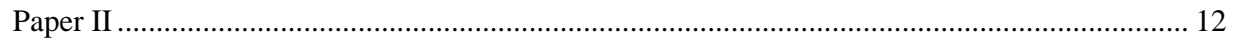

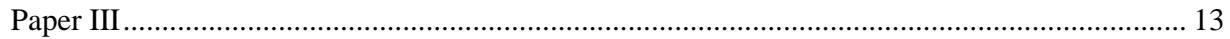

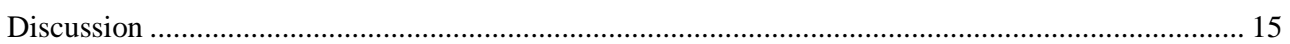

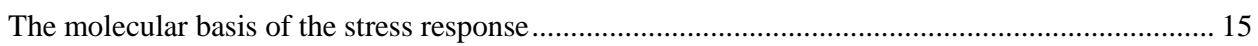

Effects of domestication on stress-related gene expression ........................................................... 15

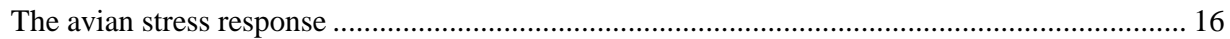

The pituitary gland as a regulator of domestication-related differences ........................................... 17

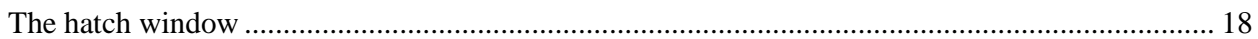

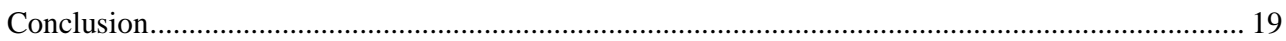

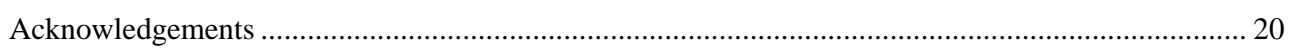

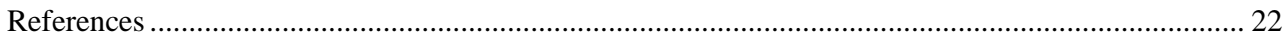





\section{Introduction}

\section{Domestication}

Domestication is the process where animals become adapted to living in proximity to humans (Price, 1999, 1984). The domestication process was recognized already by Darwin as more than just taming an animal. Rather, he observed, domestication was a goal-oriented action, with domesticated animals sharing a set of distinct behavioral and morphological traits (Darwin, 1868, 1859).

In later times, these common traits observed in domesticated animals have been termed "the domestic phenotype" (Price, 1999). They include morphological differences such as changes in coat color, decreased skull size and changes to body size. Behavioral differences observed include more tame and docile individuals, with lower fearfulness. Physiological changes are also present, including an attenuated physiological stress response and altered reproduction cycles (Wilkins et al., 2014).

Domestication is an evolutionary process, where selection pressure exerted by humans have led to genetic changes in the domesticated animals (Price, 1984). The exact nature of this selection pressure is under investigation, and a possible theory is that the domestic phenotype has evolved mainly due to selection for tameness and reduced fear of humans (Belyaev, 1979; Price, 1984). Selecting for tame individuals should lead to animals that are easier for humans to handle and to keep in captivity. However, while animals were selected for tameness, genetic mechanisms such as linkage and pleiotropy have also led to indirect selection for seemingly unrelated phenotypes such as coat color.

Selection experiments in modern times, on foxes (Gulevich et al., 2004), rats (Albert et al., 2008) and chickens (Agnvall et al., 2017), have confirmed that selecting only for tameness can in fact lead to the emergence of several of the traits included in the domestic phenotype. For example, in chickens, selecting for tameness over only eight generations have led to the low-fear line having larger growth and body size, laying larger eggs, having a modified metabolism and increased feed efficiency, and displaying a reduced brain size and a modified social behavior. Changes were also observed in gene expression and DNA methylation in the brain (Agnvall et al., 2017).

\section{Chicken domestication}

The chicken (Gallus gallus) was domesticated approximately 8000 years ago in several domestication centers in Eastern Asia (Xiang et al., 2014). The Red Junglefowl (RJF) is considered the ancestor of all domesticated chicken breeds (Fumihito et al., 1996; Storey et al., 2012; Tixier-Boichard et al., 2011).

Although the original domestication events took place a long time ago, the selection pressure on domesticated chickens has intensified markedly over the last century, similar to other domesticated animals species (Tixier-Boichard et al., 2011). This has caused modern chicken breeds to have a massively increased production capacity, for example in terms of meat yield 
in broiler chickens (Zuidhof et al., 2014), and egg mass and number in laying hens (Nicol, 2015) (Figure 1).

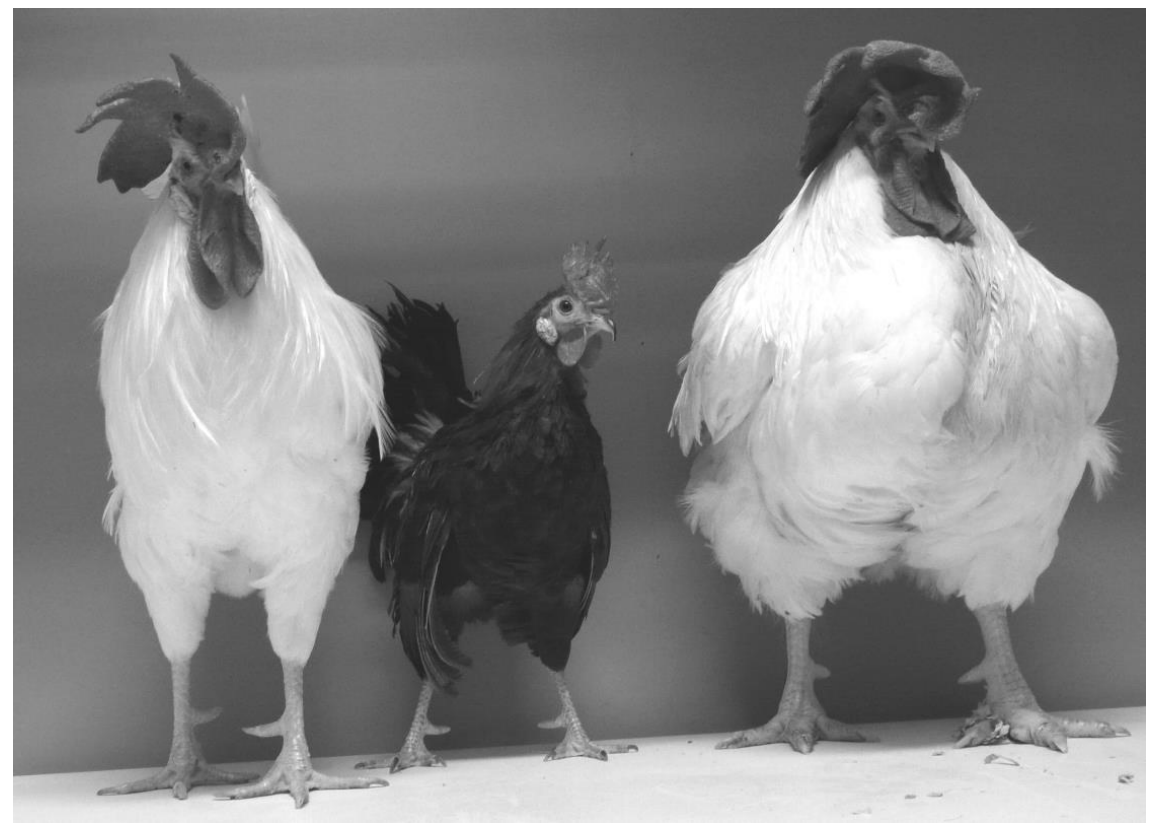

Figure 1: Adult male chickens of the ancestral breed Red Junglefowl (middle), a domesticated White Leghorn selected for egg production (left) and a broiler selected for high meat production (right).

(Photo: Anna-Carin Karlsson)

Apart from changes to production capacity, domestication has led to several other changes in the chicken. Many of these traits are consistent with the domestic phenotype. For example, domesticated chickens have a higher growth rate, become sexually mature earlier, show lower fearfulness and display an attenuated hormonal stress response compared to the RJF (Campler et al., 2009; Ericsson et al., 2014; Fallahsharoudi et al., 2015; Kerje et al., 2003; Schütz et al., 2004).

The fact that the RJF still exists and is available both in its original environment and in zoos all over the world, makes the chicken an excellent model for studies of the process and effect of domestication.

\section{Stress}

Stress can be defined as an individual's response to real or perceived threats to homeostasis (McEwen, 2007). Maintaining homeostasis means keeping vital bodily functions stable within a normal level (McEwen and Wingfield, 2003). Thus, the stress response constitutes a mechanism to defend the body against potential disruption of homeostasis.

Two major pathways are involved in the regulation of the stress response, namely the sympatho-adrenomedullary system (SAM) and the hypothalamic-pituitary-adrenal (HPA) axis. 


\section{The sympatho-adrenomedullary system}

The SAM involves neural signals going from the central nervous system to the adrenal medulla, leading to the release of adrenaline and noradrenaline. Its function is to prepare the body for action, the so-called "fight or flight" response (Sabban and Kvetňanský, 2001). The SAM is activated rapidly in the event of stress exposure, and its function is to ensure that the muscles have sufficient access to glucose and oxygen. Thus, heartrate, cardiac output, blood pressure and glucose levels are all increased (Sapolsky et al., 2000).

\section{The hypothalamic-pituitary-adrenal axis}

In contrast to the SAM system, the HPA axis is a somewhat slower acting system. When an individual is exposed to stress, neural signals reach the hypothalamus, which then releases corticotropin-releasing hormone $(\mathrm{CRH})$. $\mathrm{CRH}$ is transported through portal vessels to the anterior pituitary, where it stimulates the release of adrenocorticotropic hormone (ACTH) into the general circulation. When ACTH reaches the adrenal glands, glucocorticoids are released. In most mammals, the main glucocorticoid is cortisol, whereas in birds, reptiles and rodents, it is corticosterone.

Some of the important functions of glucocorticoids are increased glycogen breakdown and gluconeogenesis (Coderre et al., 1991; Exton, 1979; Munck et al., 1984; Myers et al., 2014). However, glucocorticoid receptors are present in most tissues, and the effect of glucocorticoids on these tissues vary considerably. The overall function is, however, to redistribute resource allocation in such a way that immediate survival may be promoted (Herman et al., 2016). For example, blood loss is counteracted, and energy may be mobilized for necessary functions. On the other hand, functions that are not necessary for immediate survival are temporarily shut down. These include reproductive function, digestion and the immune system (Herman et al., 2016).

Upon activation of the HPA-axis, the ability to survive an acute challenge is increased, and the HPA response is thus beneficial short-term. However, long-term exposure to stress, with a resulting chronic elevation of glucocorticoids, may be very harmful for the organism. Such long-term exposure has been related to various diseases (Chrousos, 2009; de Kloet et al., 2005).

Normal functioning of the HPA axis is modulated by the glucocorticoids' negative feedback on themselves. As the level of glucocorticoids in the blood increases, glucocorticoids bind to receptors on several levels of the HPA axis, and start shutting down activity of the axis (Chrousos, 2009; de Kloet et al., 2005; Keller-Wood, 2015; Vandenborne et al., 2005).

\section{The HPA axis in detail}

Although the HPA axis has received its name from its main constituting tissues (hypothalamus, pituitary and adrenal glands), other tissues are also involved. Modifications to the activity of the HPA axis is possible through changes to gene functioning, gene expression and protein translation in all of these tissues. The following sections give a more detailed 
overview of these different tissues, with particular focus on genes that may be altered to change the overall response of the HPA axis.

\section{Hypothalamus}

The hypothalamus constitutes an important connection between the nervous system and the endocrine system (Nelson, 2005). Information from all areas of the brain descend to the hypothalamus, and the hypothalamus then translates these signals into endocrine signals. Thus, the hypothalamus releases hormones such as $\mathrm{CRH}$, thyrotropin-releasing hormone (TRH), growth hormone-releasing hormone (GHRH), gonadotropin-releasing hormone (GnRH) and somatostatin (Nelson, 2005).

$\mathrm{CRH}$ is encoded by the $C R H$ gene, and it is produced in parvocellular neurons in the paraventricular nucleus of the hypothalamus (Herman et al., 2016). Thereafter, it is transported to the median eminence and released into the portal vessels that connect the hypothalamus with the anterior pituitary. Another hormone, arginine vasopressin (AVP) is also produced and released together with CRH (Aguilera and Rabadan-Diehl, 2000), and both of these hormones induce secretion of ACTH from the pituitary (Herman and Cullinan, 1997). Thus, the PVN is a crucial brain region for the control of the HPA axis.

\section{Pituitary}

The pituitary is an endocrine gland situated just below the base of the brain, connected to the hypothalamus through both nerves and blood vessels. It functions as a relay point between the hypothalamus and the rest of the body. The hypothalamus sends various signals to the pituitary, which in turn releases different hormones into the general blood stream (Nelson, 2005).

The pituitary consists of two different endocrine glands, the anterior and the posterior pituitary. The anterior pituitary receives hormonal signals from the hypothalamus, such as CRH, GnRH, GHRH and TRH (Nelson, 2005), involved in diverse processes such as the stress response, the reproductive system and metabolism.

The posterior pituitary, on the other hand, receives direct neural signals from the hypothalamus through hypothalamic neurons extending down into the posterior pituitary. Two hormones, oxytocin and vasopressin, or vasotocin in birds, are produced in the cell bodies of these neurons, and thereafter transported down the axons and stored in the posterior pituitary. Upon neural signaling, these stored hormones may quickly be released into the body (Nelson, 2005).

As mentioned previously, when an individual experiences stress, $\mathrm{CRH}$ is released from the hypothalamus into the portal vessels leading to the pituitary. Upon reaching the anterior pituitary, $\mathrm{CRH}$ binds to $\mathrm{CRH}$ receptor 1 (CRHR1) on corticotrophs. This triggers activation of downstream signaling pathways including PKA and MAPK pathways, which stimulate the synthesis and release of ACTH (Bonfiglio et al., 2011).

Ultimately, the binding of CRH to CRHR1 leads to activation of transcription factors, which in turn may stimulate the expression of the gene pro-opiomelanocortin (POMC) (Bonfiglio et al., 2011). The POMC protein is the precursor of ACTH, and it is cleaved by various 
prohormone convertases to give rise to several different hormones. The production of ACTH from POMC occurs through the actions of prohormone convertase 1 (PC1) (Benjannet et al., 1991).

The synthesis and release of ACTH is also modulated by the binding of CRH to CRH receptor 2 (CRHR2) and of AVP to AVPR1B (Bonfiglio et al., 2011). Furthermore, the binding of glucocorticoids to glucocorticoid receptors (GR) in the pituitary inhibits both the release of ACTH and the synthesis of POMC (Martens et al., 2005).

\section{Adrenal glands and steroidogenesis}

The adrenal glands are the location for the synthesis of glucocorticoids, the steroidogenesis (Payne and Hales, 2004). All steroids are produced from cholesterol, and the initial step in this process is the transportation of cholesterol into the intermembrane space of the mitochondria. This transportation is mediated by the steroidogenic acute regulatory protein (STAR) (Lin et al., 1995). Once in the mitochondria, cholesterol is converted to pregnenolone by the enzyme Cytochrome P450 family 11 subfamily A member 1 (CYP11A1) (Payne and Hales, 2004). Pregnenolone may in turn be further processed, via various steps and with the help of a number of enzymes, into several steroid hormones, including corticosterone, cortisol, aldosterone, testosterone and estradiol (Payne and Hales, 2004).

While the transportation of cholesterol by STAR and the initial conversion of cholesterol are generally considered rate-limiting steps in the synthesis of glucocorticoids (Lin et al., 1995; Payne and Hales, 2004), it is possible that modifications changes to any of the involved enzymes could modulate the final output.

\section{Hippocampus}

The hippocampus is well known to play a pivotal role in the negative feedback of the HPA axis, and it is the brain region with the highest density of glucocorticoid receptors (Sapolsky et al., 1984). Upon binding of glucocorticoids to these receptors, neurons projecting from the hippocampus onto the paraventricular nucleus (PVN) of the hypothalamus inhibit the production of CRH (Fink, 2000). Alterations in the expression and translation of glucocorticoid receptors in the hippocampus thus have the potential to modify the activity of the HPA axis.

\section{Liver}

The liver is the production site of the corticosterone-binding globulin (CBG). CBG binds to corticosterone and transports it in the blood stream. It has been suggested that only the amount of corticosterone not bound to $\mathrm{CBG}$ is available for biological functions, although this is somewhat debated (Malisch and Breuner, 2010). CBG levels and affinity are also known to differ between breeds and as a result of environmental changes (Malisch and Breuner, 2010). If this is the case, however, variations in the amount of CBG produced could affect the overall response to glucocorticoids. In chickens, CBG is encoded by the gene currently annotated as serpin family A member 4 (SERPINA4) (Vashchenko et al., 2016). 
The liver is also one of the sites where inactivation of corticosterone takes place. This is mediated through the enzyme hydroxysteroid 11-beta dehydrogenase 2 (HSD11B2), which converts corticosterone into inactive cortisone (Carsia, 2014).

\section{Domestication and the stress response}

The functioning of the HPA axis has been modified in all domesticated species where this has been investigated. Domesticated species show an attenuated stress response both behaviorally and physiologically (Ericsson et al., 2014; Gulevich et al., 2004; Künzl and Sachser, 1999; Plyusnina et al., 2011; Trut et al., 2009; Weiler et al., 1998). This effect of domestication is thought to be an adaptation to the captive environment combined with selection pressure for higher reproductive capacity. As exposure to stress may lead to reproductive failure, natural selection in the captive environment should have selected for animals that were better able to survive and reproduce despite stress (Price, 1999).

In chickens, maximum corticosterone levels after exposure to stress are reached after approximately 10-15 minutes (Cockrem, 2007). Studies have shown that the chickens of the domesticated breed White Leghorn demonstrate an attenuated peak compared with Red Junglefowl (Ericsson et al., 2014; Fallahsharoudi et al., 2015).

This modification of the HPA axis may have been brought about by changes to any or many of the proteins involved in the control of its activity, but little is known about the exact mechanisms of this. In paper I, we therefore investigated gene expression at several levels of the HPA axis to try to increase the understanding of the attenuation of the stress response in domesticated animals. In paper II, we continued this work, but focused more specifically on the pituitary gland, which has rarely been investigated in this context.

\section{Early experiences}

While domestication is an evolutionary process that changes the genome of a species, early experiences can be regarded as something that happens to an individual during its early life (pre- or postnatally), and that can affect it on a long-term scale (Romeo et al., 2010; Weaver, 2009). Examples of early experiences known to affect individuals are maternal starvation (Roseboom et al., 2001), maternal care (Francis and Meaney, 1999), maternal deprivation (Andersen et al., 1999) and exposure to novelty (Tang, 2001).

One type of early experience is events taking place in the prenatal environment, that is, the environment during gestation or incubation. Numerous studies have shown that exposure to hormones, for example stress hormones, circulating in the pregnant mother or deposited into the egg by the mother at egg laying, can affect the developing offspring (Braastad, 1998; Braastad et al., 1998; Henriksen et al., 2011; Janczak et al., 2006).

\section{The hatch window}

Incubated chicken eggs hatch after approximately 21 days. However, within a normal batch of eggs, the time from the hatching of the first egg to the last can be as much as 36-48 hours (Tong et al., 2013; van de Ven et al., 2011). This time period is called the hatch window. 
The factors affecting the time of hatching are not yet completely understood. It is likely that intrinsic factors of the hatching chick will affect its hatching time, as studies have shown effects of breed and age of the mother (Ruiz and Lunam, 2002; Ulmer-Franco et al., 2010; Vieira et al., 2005), size of the egg (Careghi et al., 2005; Ulmer-Franco et al., 2010; Vieira et al., 2005), and sex of the chick (Reis et al., 1997; van de Ven et al., 2011). It is also known that differences in the developmental phase of chicken embryos incubated at the same time arise very early in incubation (Hamburger and Hamilton, 1951).

During the hatching process, several endocrine axes are involved in preparing the embryo for postnatal life, as well as facilitating hatching behavior (Tong et al., 2013). Inactive thyroxine (T4) and active 3,3',5-triiodothyronine (T3) both start to increase on day 15 of incubation, but whereas T3 continues to slowly rise until hatch, T4 decreases after internal pipping on day 19 or 20. After hatch, levels of both hormones decrease again. Higher levels of thyroid hormones have been linked to shorter hatch windows (Tong et al., 2013).

Corticosterone is also involved in the hatching process, and increasing levels of CORT during the last few days of incubation have been suggested to initiate the hatching process (Tong et al., 2013).

The process of hatching may be considered a special case of early experience. All chickens experience it, but the experience may not be the same for all individuals, and it may therefore affect them differently later in life. The time of hatching may also itself be the influenced by genetics or by maternal factors, which could in turn modify the phenotype of the individual.

Several studies have shown that the time of hatching is correlated with phenotypes of the individual later in life, including differences in growth (Careghi et al., 2005; Nielsen et al., 2010; Tona et al., 2003; van de Ven et al., 2011), and some differences in hormone levels and maturity (van de Ven et al., 2011). However, apart from one study on feeding behavior (Nielsen et al., 2010), knowledge about the effects of hatching time on behaviors is very scarce. In paper III, we therefore investigated the effects of different hatching times of chickens on behavior and growth. 


\section{Aims of the thesis}

The aims of this thesis fall into two main categories.

The first aim, investigated in papers I and II, was to gain a better understanding of the genetic processes that underlie differences between the ancestral Red Junglefowl and the domestic White Leghorn. Special emphasis was placed on the stress response, and investigations were performed on various tissues involved in the hypothalamic-pituitary-adrenal axis.

The second aim, which was investigated in paper III, was to expand knowledge about phenotypes correlated with hatching time in chickens. In this case, special emphasis was placed on behavior, but growth was also investigated. 


\section{Methods}

While the methods used are described in each paper, some details warrant a more in depth explanation.

\section{Animals}

In Paper I and Paper II, comparisons were done between Red Junglefowl (RJF) and White Leghorn (WL).

The RJF population used in these studies originated from a Swedish Zoo population, which originally was brought from Thailand to Sweden (Schütz et al., 2001). After two generations, animals were brought from the zoo population to research facilities, and they have been kept in our facility during approximately 15 generations. Breeding has been carefully supervised using pedigree information to ensure maintenance of genetic variability, although some degree of inbreeding has been unavoidable.

The WL population used for these studies (SLU13) is a research line originating from the Scandinavian selection and crossbreeding experiment selected for egg mass (Liljedahl et al., 1979).

For paper III, we bought fertile eggs of the white commercial laying hybrid Bovans from a local hatchery. The Bovans white strain is, according to Hendrix Genetics (The Netherlands), the company producing Bovans chickens, a robust and easy to manage strain, with good balance between performance, feed efficiency and livability.

\section{Gene expression measurements}

\section{Quantitative PCR}

Quantitative PCR (qPCR) is a method that can be used to measure relative levels of DNA or RNA in a sample. The basic mechanism is similar to that of normal PCR, with amplification of a target sequence. However, incorporation of fluorescent molecules into the newly synthesized DNA and subsequent measurements of the fluorescence level allows for estimation of the original amount of the target sequence relative to control genes and to other individuals (Gibson et al., 1996; Nolan et al., 2006). qPCR was used in Paper I of this thesis.

\section{Microarray}

A disadvantage of qPCR is that the number of genes that can be investigated is rather low, and the genes must be handpicked for each study. Microarrays are chips with DNA sequences attached to them. These DNA sequences target complementary sequences in the genome of an organism, and a single chip may contain hundreds of thousands of different sequences. cDNA from samples can be hybridized onto the microarray chip, and similar to qPCR, measurements of fluorescence levels indicate relative amounts of different mRNAs in the sample. Thus, information can be gained about levels of gene expression of a vast number of genes, without making any assumption about which genes are related to the hypothesis of the study (Schena et al., 1995; Schulze and Downward, 2001). Microarray was used in Paper II of this thesis. 


\section{Paper summaries}

\section{Paper I}

Chicken domestication changes expression of stress-related genes in brain, pituitary and adrenals

Pia Løtvedt, Amir Fallahshahroudi, Lejla Bektic, Jordi Altimiras, Per Jensen

Neurobiology of Stress (2017), 7, 113-121.

\section{Aims and method:}

The aim of this study was to gain more insight into the genetic mechanisms underlying the chicken stress response and the differences between ancestral Red Junglefowl (RJF) and domestic White Leghorn (WL).

We exposed males of both breeds to 45 minutes of restraint stress treatment. We then compared the gene expression of selected genes in five different tissues with control animals. The tissues utilized were the hippocampus, hypothalamus, pituitary, adrenal glands and liver, and the genes were chosen based on their known or suspected functions in the stress response.

\section{Results and conclusions:}

Several genes differing in expression between the two breeds were found in the investigated tissues, including the gene encoding the glucocorticoid receptor (NR3C1) in the hypothalamus, POMC and $P C 1$ in the pituitary and CYP11A1 and HSD3B2 in the adrenal glands. These findings are in line with the attenuated stress response observed in the WL, as they suggest that WL may have a higher capacity for negative feedback of the HPA axis, a lower capacity for synthesis of ACTH in the pituitary and a reduced synthesis rate of corticosterone in the adrenal glands compared to RJF.

Furthermore, exposure to stress resulted in upregulation of genes such as FKBP5, C-FOS and EGRI in hippocampus and hypothalamus and STAR, $M C 2 R$ and $T H$ in adrenal glands. These patterns were similar to those observed in mammals, but several of them are novel findings for avian species.

In the pituitary, we found a decrease in the expression of CRHRI, EGRI and C-FOS after stress. These changes could affect the stress response as well as reproduction and growth. Studies on the pituitary of chickens are scarce, particularly in relation to the stress response, and further investigations on gene expression in the pituitary gland would contribute much to our current limited knowledge. 


\title{
Paper II
}

Alterations in the gene expression pattern of the pituitary is consistent with domestication effects on the stress response in chickens

Amir Fallahshahroudi, Pia Løtvedt, Johan Bélteky, Jordi Altimiras, Per Jensen

Manuscript

\begin{abstract}
Aims and methods:
The aim of this study was to gain a deeper understanding of gene expression in the pituitary of chickens, both in relation to domestication and to stress exposure. Red Junglefowl (RJF) and White Leghorn (WL) pituitaries from 5 week old birds were sampled at baseline and after 15 minutes of restraint stress. The transcriptomes of these pituitaries were investigated using microarray analysis, allowing for measurement of approximately 20000 different genes.
\end{abstract}

\section{Results and conclusions:}

946 transcripts were found to be differentially expressed in the pituitaries of the two breeds. 489 of these were annotated genes. Among genes that were downregulated in the WL were $S S T R 1$, involved in inhibition of growth, and FST, involved in inhibition of puberty and reproduction. Interesting genes that were upregulated in WL include genes that inhibit the HPA axis activity ( $G R$ and $C R H R 2$ ), genes that modulate the stress response (AVPRIA and $A V P R 1 B)$, genes that stimulate metabolism and reproduction (TSHB and DIO2) and genes that modulate reproduction, broodiness and molting ( $P R L R, M T N R I B$ and $P G R$ ). These results suggest that transcription of several important modulatory genes in the pituitary have been affected by domestication.

14 transcripts were differentially expressed between control animals and stressed animals. Some of these genes were involved in G protein-coupled signaling ( $R S G 1)$ and in pre-RNA slicing and glycogen regulation $(P P P 1 R 14 D)$. Only one gene showed a significant breed $\times$ treatment interaction after correction for multiple testing, the DUSP4. This gene is part of a negative feedback mechanism for $\mathrm{GnRH}$, decreasing the sensitivity of the gonadotrophs to stimulation by this hormone, and it could thereby decrease the release of FSH or LH, or both. DUSP4 expression was increased in RJF after stress, but decreased in WL. This gene could therefore be a crucial part of the mechanisms affecting reproductive abilities after stress exposure in domestic and ancestral chickens.

Overall, this study provides strong indications that regulation at the level of the pituitary underlie traits involved in the domestic phenotype, such as attenuated stress response, increased growth rate, earlier sexual maturity and lack of seasonal reproduction and broodiness. 


\title{
Paper III
}

\section{Effects of hatching time on behavior and weight development of chickens}

Pia Løtvedt, Per Jensen

PloS one (2014), 9, e103040.

\begin{abstract}
Aims and methods:
The aim of this paper was to investigate the effects of differences in hatching time on behavior and growth of chickens. Eggs were incubated and tracked during hatching, and the time of hatching was recorded. The first and last hatching chicks, as well as a group from the middle of the hatch window, were selected for further investigations.

The chicks were tested with a number of behavioral tests from the age of three weeks up until 8 weeks. These results were subjected to a principal components analysis. Throughout the study period, the animals were also weighed on several occasions to track their growth.
\end{abstract}

\section{Results and conclusion:}

In males, several behaviors differed between the three hatch groups, particularly between early and middle hatchers. Early hatchers showed a stronger response to novelty as well as a tendency of higher activity compared to middle hatchers. In a spatial learning test, late hatchers tended to learn slower.

In females, no behavior was significantly affected by hatching time, however their body weights were negatively correlated with hatching time from 4 days of age until the end of the study at 56 days of age.

Very few studies have previously investigated effects of hatching time on behavior. These results may therefore contribute both to the understanding of potential evolutionary trade-offs between length of incubation and post-hatch traits, and to knowledge about effects of early experiences in chickens. 


\section{Discussion}

\section{The molecular basis of the stress response}

Attenuation of the stress response is a well-known trait of the domestic phenotype (Ericsson et al., 2014; Gulevich et al., 2004; Künzl and Sachser, 1999; Plyusnina et al., 2011; Trut et al., 2009; Weiler et al., 1998). By investigating gene expression on various levels of the HPA axis in ancestral and domesticated chickens, we have discovered a number of genes differing in expression between these two breeds. Thus, this work has increased our understanding of mechanisms that may underlie the attenuation of the HPA axis activity. Additionally, we have gained novel information about the avian stress response, a topic that is not as well understood as the mammalian stress response.

\section{Effects of domestication on stress-related gene expression}

Investigations of several tissues of the HPA axis showed a number of genes known to be involved in the stress response that differed in expression between the breeds (paper I and paper II). We discovered that RJF had a higher expression of pro-opiomelanocortin (POMC) and prohormone convertase $1(\mathrm{PCl})$ in the pituitary (paper I). As the protein POMC is the precursor for ACTH, and PC1 is the enzyme that cleaves POMC (White and Gibson, 1998), this indicates a higher capacity for ACTH production in the RJF. We also found higher expression of the gene encoding the glucocorticoid receptor (GR), nuclear receptor subfamily 3 group C member 1 (NR3C1) in the pituitary of WL (paper II), suggesting that increasing plasma levels of corticosterone may lead to more efficient negative feedback of the HPA axis activity in these animals (Herman et al., 2016; Keller-Wood, 2015). This could explain the attenuated peak of corticosterone release in WL compared to RJF. Similarly, a higher expression of $N R 3 C 1$ in the hypothalamus of WL (paper I) could also lead to increased negative feedback capacity in the domesticated breed (Keller-Wood, 2015).

Furthermore, we found lower expression of $C R H R 2, A V P R 1 A$ and $A V P R 1 B$ in the pituitary of the WL (paper II). The function of CRHR2 in the pituitary is somewhat unclear, but it may be involved in modulation of the HPA axis (Preil et al., 2001) and in anxiety-related behavior (Aguilera et al., 2004; Kishimoto et al., 2000). AVPR1B encodes a receptor for AVP, and in the pituitary, AVP binding to this receptor stimulates activity of the HPA axis (Aguilera and Rabadan-Diehl, 2000).

Interestingly, when we investigated gene expression after 15 minutes of stress exposure, we found a significant interaction between breed and stress treatment for the gene dual specificity phosphatase 4 (DUSP4) (paper II). This gene is involved in the secretion of gonadotropins, and an increased expression leads to desensitization of the gonadotrophs to GnRH (T Zhang et al., 2001; Tong Zhang et al., 2001). The fact that the expression levels of this gene increase after stress in RJF and decrease in WL is a striking finding, and further studies should be undertaken to better understand the importance of changes to DUSP4 expression during domestication.

In the adrenal glands, we discovered that the domesticated WL have lower expression of the genes CYP11A1 and HSD3B2 (paper I). These genes encode enzymes involved in the synthesis of corticosterone (Payne and Hales, 2004), and this result thus suggests that 
production capacity of corticosterone of the ancestral breed is higher than that of the domesticated breed.

Overall, these results are in line with the previous observations that WL display a lower poststress peak in corticosterone plasma concentrations (Ericsson et al., 2014; Fallahsharoudi et al., 2015). However, we must be somewhat careful with inferring biological effects based on measurement of gene expression. Although mRNA levels may be correlated with protein levels, this is not always the case (Maier et al., 2009). Investigating protein levels of the genes we have identified in our studies would therefore add another layer of important information.

Assuming that our findings on gene expression levels translate to protein levels, we can hypothesize around the causal mechanism of the observed changes. Modulation of gene expression in the pituitary could for example be a result of changes to hypothalamic functioning, as much of the activity in the pituitary is governed by the hypothalamus. However, investigations of the hypothalamic transcriptome of ancestral and domesticated chickens did not identify genes well known to be involved in HPA axis activity (Nätt et al., 2012).

Another possibility is that changes to master regulatory genes affect a multitude of pathways in the pituitary, leading to more widespread changes (Tapscott, 2005; Wang et al., 2003). Alternatively, selection on genetic variation in many independent regulatory elements could also explain effects on gene expression. Studies using pathway analyses (Khatri et al., 2012) or a systems biology approach (Draghici et al., 2007; Ideker et al., 2001) could potentially give further insight into this question.

\section{The avian stress response}

Although a main focus of the thesis has been to investigate differences between domesticated and ancestral chickens, we have also gained new insight into the avian stress response.

When comparing expression during normal conditions and after 45 minutes of stress, we found patterns that were similar to those observed previously in mammals (paper I) (Herman et al., 2016; Pozzoli et al., 1996; Sabban and Kvetňanský, 2001). Thus, we saw upregulation of the genes early growth response 1 (EGRl), C-FOS and FOSL2 in hippocampus, hypothalamus, and adrenals, and a decrease of corticotropin releasing hormone receptor 1 $(C R H R 1)$ expression in the pituitary. We also found upregulation of genes involved in the steroidogenesis, such as steroidogenic acute regulatory protein (STAR), in the adrenal glands after stress. The gene encoding the adrenal gland receptor for ACTH, melanocortin 2 receptor $(M C 2 R)$, and genes encoding its accessory proteins melanocortin 2 receptor accessory protein $(M R A P)$ and melanocortin 2 receptor accessory protein 2 (MRAP2), also increased after stress.

However, we also found some less well-known changes after stress, such as a downregulation of EGRI and $C$-FOS in the pituitary after 45 minutes of stress exposure (paper I). While the functions of these genes in the pituitary have not been studied extensively, previous studies suggest that EGRl could be involved in the pathway linking GnRH stimulation to the secretion of gonadotropins (Ferris and Shupnik, 2006; Tremblay and Drouin, 1999; Wolfe and Call, 1999). 
We also investigated gene expression in the pituitary gland after 15 minutes of stress exposure (paper II). As expected, very few changes in gene expression were found so shortly after onset of stress treatment, and it is likely that the genes that were affected at this point are very early responding genes. Most interesting among these genes were protein phosphatase 1 regulatory inhibitor subunit $14 D(P P P 1 R 14 D)$ and regulator of $G$ protein signaling 1 (RGS1). PPP1R14D encodes a protein involved in both pre-mRNA slicing (Eto, 2009; Liu et al., 2004; Shi et al., 2006), as well as glycogen metabolism and signaling (Karthik and Ravikumar, 2011). While we currently do not know its function in the pituitary after stress, it possible that it is involved in the expression and translation of proteins that respond more slowly to stress. $R G S 1$ encodes a protein involved in $\mathrm{G}$ protein signaling (Kim et al., 2010). A number of important receptors in the pituitary gland are G protein coupled receptors (Alexander et al., 2013), and further investigations should look into whether the RGS1 protein interacts with the functioning of these, and if this is affected by stress exposure.

Overall, we have identified a number of genes may have important functions in the modulation of the stress response of avian species. Understanding the mechanisms of the stress response of birds may be of great importance in improving their conditions and welfare in production settings, where animals are exposed to various types of stress. If genes can be identified that have a large effect on stress reactivity, and subsequently animal welfare, conscious selection targeting beneficial genetic variants could be successful.

\section{The pituitary gland as a regulator of domestication-related differences}

While investigating the early response of gene expression in the pituitary to stress was an important focus of paper II, this study is also among the very first to compare the pituitary transcriptome in domesticated and ancestral breeds. The results of this comparison were very interesting, allowing us to gain a better understanding of gene expression differences underlying main physiological traits that have evolved due to domestication. Overall, 946 transcripts were differently expressed between the two breeds. Aside from NR3Cl, CRHRl, $A V P R 1 A$ and $A V P R 1 B$, discussed previously in relation to the stress response, we found expression differences in several other genes involved in the most important functions of the pituitary gland.

One of these genes, somatostatin receptor 1 (SSTR1), is involved in the inhibition of growth (Ben-Shlomo and Melmed, 2010). As somatostatin is released from the hypothalamus and transported to the pituitary, it binds to SSTR1, which leads to inhibition of growth hormone release (Kreienkamp et al., 1999). The expression of SSTRI was higher in RJF, and as the WL breed grows to a much larger body size than RJF, it is plausible that SSTRI could be involved in this.

Among the differentially expressed genes, we also found genes that are involved in puberty and reproduction. The gene encoding follistatin (FST), which inhibits follicle-stimulating hormone (FSH) (Depaolo et al., 1991; Robertson et al., 1990; Wang et al., 1990; Ying et al., 1987) and therefore affects reproduction, was expressed higher in RJF. TSHB and DIO2 stimulate metabolism and reproduction (Nakao et al., 2008), whereas PRLR, MTNR1B and PGR modulate seasonal behavior, including reproduction, molting and broodiness (Wilkanowska et al., 2014), and these genes were all expressed higher in WL. 
It is rather striking to find expression differences in a suite of genes so intimately involved in physiological functioning in the pituitary of ancestral and domesticated individuals. The results indicate that modification of activity in the pituitary could explain the phenotypic changes associated with the domestic phenotype. As discussed previously, the origins of the observed differences, whether they are caused by modification to upstream regulators, or selected for individually throughout domestication, are yet to be understood.

A main concern regarding these results is the fact that they are obtained through a comparison of only two breeds. Thus, as much as the results make sense in the light of traits modified by domestication, more evidence must be gathered to further support the hypothesis that the observed differences can explain the domestic phenotype. At present, only one other such study is available (Hekman, 2017), an investigation of the pituitary transcriptomes of tame and aggressive foxes originating from the domestication experiment of Dmitry Belyaev (Belyaev, 1979). While the study on foxes does not report differential expression of any genes that overlap with our own results, the full gene list is not yet available, and we are therefore not able to make any in depth comparisons between our and their set of genes.

Some other studies do identify candidate genes for domestication-related changes. In a study on regions targeted by selection during domestication of rabbits, SSTR1, NR3C1 and PRLR were identified within such regions (Carneiro et al., 2015). PRLR is also situated in a quantitative trait loci for growth in chickens (Kerje et al., 2003), and is differently expressed in the adrenal glands of tame and aggressive foxes (Hekman, 2017). DIO2 is located close to the TSHR selective sweep identified in chickens (Rubin et al., 2010). Thus, there is some further evidence to support the involvement of these genes in the domestic phenotype.

A natural next step would be a similar comparison of the pituitary transcriptomes of other pairs of ancestral and domesticated breeds and species, such as wolves and dogs (CluttonBrock, 1995), wild boar and domesticated pigs (Larson et al., 2005) and wild and domesticated rabbits (Carneiro et al., 2014).

\section{The hatch window}

A second aim of this thesis was to investigate the effects of different hatching times on behavior and growth of chickens (paper III). As hatching time can be seen as a type of early experience, and as early experiences are well known to affect later phenotypes, we hypothesized that differences in time of hatching would have effects on the chickens later in life.

We found that the effects observed were sex specific, as behavior was affected in males and growth was affected in females. The fact that early hatching females weighed more than late hatching females is in line with previous studies on the hatch window (Careghi et al., 2005; Tona et al., 2003; van de Ven et al., 2011), but the mechanism for this is not known. Based on previous findings (Buys et al., 1998; Careghi et al., 2005; van de Ven et al., 2011), we suggest performing further investigations on thyroid hormone levels in early and late hatchers.

In males, on the other hand, we saw an effect of hatching time on behavior, with early hatching males having a stronger response to novelty as well as a tendency for higher activity and faster spatial learning. Very few studies have investigated hatching time and behavioral consequences, and thus, our results provide novel insights. As of yet, we do not know any 
mechanism underlying this link, but as hormones are a crucial part of the hatching process (Decuypere and Bruggeman, 2005), and can also have large effects on behavior, we can hypothesize that changes to hormone levels may be the explanation. We suggest that investigations should start with corticosterone, since this hormone is known to often cause sex-specific effects (Groothuis et al., 2005), can have profound effects on later life phenotypes (Henriksen et al., 2011), and is an important hormone in the hatching process (Decuypere and Bruggeman, 2005).

The results from this study may provide insight into how batch homogeneity can be achieved, a topic that is important in chicken industry, where differences among individuals in a batch should be as small as possible. However, the findings are also interesting in terms of understanding effects of early experiences. Future studies on this topic might want to consider the theory of maternal programming. According to this theory, mothers can modify the early environment of their offspring to program their later phenotypes. This is believed to prepare the offspring for environments they will experience later in life (Bateson et al., 2004). Deposition of hormones into the egg, potentially modulating both incubation length and other traits such as growth and behavior, would be one possible mechanisms for maternal programming.

\section{Conclusion}

In summary, this thesis has contributed new knowledge in several areas. We have uncovered novel information regarding the stress response in domesticated chickens, we have discovered more general differences between ancestral and domesticated chickens, and we have also investigated, and found, effects of early experiences, more specifically the special case of the hatch window, on behavior and growth of chickens.

Our results open up new, interesting questions for further research. We have identified several potential mechanisms for many of the differences we have found, and these should be investigated. In particular, the area of gene expression in domesticated and ancestral breeds has the promise of being a fruitful area of research. We believe that investigations of other pairs of domesticated and ancestral animal breeds may strengthen the evidence that we have identified important mechanisms underlying the domestic phenotype. 


\section{Acknowledgements}

This thesis would not exist if not for the help and support of many people. I would especially like to thank:

Pelle, my supervisor, for all help you have given me, and all patience and understanding you have shown me. I can't begin to say how grateful I am that you gave me the chance to do this, and that you have allowed me to finish it in my own way.

Jordi, my co-supervisor. Thank you for the fantastic support you have given me, and for taking your role as co-supervisor so seriously. I have enjoyed our lunch meetings so much, and you have always helped me see my research from new perspectives.

Amir. Without you, there definitely wouldn't be a thesis at all. When I had no energy myself to make plans for my research and my future, you started including me in your plans. You've helped me back on my feet, back to the lab, and back to the writing. I can't thank you enough for this.

Johan, you were my supervisor in the lab from my very first experiment as a master student, to my very last when I did the microarrays. I'm sure my experiments would all have been messed up if it hadn't been for all the stuff you taught me.

Ann-Charlotte, thanks for all expertise you've shared with me in the lab and all the questions you've patiently answered, but also for all the good talks we've had about life and hockey. Tove, thank you for being a solid support during my teaching adventures, and for answering the same questions every year when I've forgot what we said the year before.

Lejla and Petros, you have been amazing. I could always count on you for help in my experiments, no matter how big and exhausting they were. On those long days of chicken work, you always made sure chaos didn't happen, and at the same time you were such superb company.

Jenny, thank you for bringing me along on the genetics course and giving me so much responsibility, I loved teaching that course. Your hard work to always improve the course is incredibly inspiring. Kjempefint!

LiU-eliten: Anna-Carin, Ann-Sofie, Bea, Josefina, Karin and Mia. What a source of PhD wisdom and life experience! Our monthly dinners are the best, and whenever I need advice, or just someone to brainstorm with, you are among the first I turn to. You've all helped me in so many ways, and during this last intensive time of working with the thesis, your support has been incredible.

I would also like to thank Magnus for being such an awesome office buddy, Matthias for supervising me when I was a little master student, Martin $\mathbf{J}$ for being the god of statistics and R and microarrays, Anna for keeping track of pretty much everything, Andrey for helping me on the way to making my thesis cover, and everyone at the Biology department for creating such an amazing place to work. 
Johanna, du får ett extra extra stort tack. Tack för att du är en så fantastisk vän, för att du förstår mig bättre än jag förstår mig själv, för alla kattbilder och för att du skrattar med mig åt dom allra fånigaste skämten. Tack för alla jobbdejter, promenaderna, alla koppar med te, alla peptalks. Och för att du bryr dig om Svante och Sebbe som om dom vore dina egna. Tack för att du hittade alla fel $\mathrm{i}$ den här avhandlingen, och att du räddade mig från att skriva hypochondria istället för mitochondria, hur roligt det än vore. Tack för att du är du $<3$

Mamma og Ab. Takk for den uendelige støtten jeg får fra dere, og for at dere alltid vil det beste for meg. For at dere alltid stiller opp og vil være der for meg, og for at dere lar meg gå min egen vei. Mamma, jeg setter så stor pris på alt du har gjort for meg. Det er så fint å kunne ringe til deg og klage litt når ting er slitsomme, som når man skriver avhandling. Og så er det like fint å ringe og fortelle når det skjer bra ting. Som når man blir ferdig med å skrive avhandling. Takk for at du alltid hører på meg. Veldig glad i dere begge.

Svante och Sebbe, mjao. Ni får mig att skratta varenda dag, och det bästa som finns är att mysa med er på soffan. Ni har varit fantastiska thesis buddies och hängt med mig hela tiden under skrivandet. Helst mellan mig och skärmen. Otroligt att jag fick något gjort egentligen. Tack för att ni håller ut med etologen i mig, som alltid tycker att ni ska göra en massa fåniga tricks bara för att få lite kattgodis. Tänk att just ni kom hem till mig och husse, ni är helt underbara.

Anders, bästa Anders. Att få dela mitt liv med dig är fantastiskt. Du har varit med mig genom så mycket, och tack vare dig har det som har varit jobbigt gått lite lättare, och det som har varit bra har blivit ännu bättre. Ditt stöd och din tro på mig är ovärderliga. Jag är så tacksam för att du har hjälpt mig att hitta rätt väg i mitt liv, och att du har låtit mig göra det i min egen takt. Jag ser fram emot alla äventyr och alla vardagar som vi ska dela i framtiden. 


\section{References}

Agnvall, B., Bélteky, J., Katajamaa, R., Jensen, P., 2017. Is evolution of domestication driven by tameness? A selective review with focus on chickens. Appl. Anim. Behav. Sci. doi:10.1016/j.applanim.2017.09.006

Aguilera, G., Nikodemova, M., Wynn, P.C., Catt, K.J., 2004. Corticotropin releasing hormone receptors: Two decades later. Peptides 25, 319-329. doi:10.1016/j.peptides.2004.02.002

Aguilera, G., Rabadan-Diehl, C., 2000. Vasopressinergic regulation of the hypothalamicpituitary-adrenal axis: Implications for stress adaptation. Regul. Pept. 96, 23-29. doi:10.1016/S0167-0115(00)00196-8

Albert, F.W., Shchepina, O., Winter, C., Römpler, H., Teupser, D., Palme, R., Ceglarek, U., Kratzsch, J., Sohr, R., Trut, L.N., Thiery, J., Morgenstern, R., Plyusnina, I.Z.,

Schöneberg, T., Pääbo, S., 2008. Phenotypic differences in behavior, physiology and neurochemistry between rats selected for tameness and for defensive aggression towards humans. Horm. Behav. 53, 413-421. doi:10.1016/j.yhbeh.2007.11.010

Alexander, S.P.H., Benson, H.E., Faccenda, E., Pawson, A.J., Sharman, J.L., Spedding, M., Peters, J.A., Harmar, A.J., 2013. The Concise Guide To Pharmacology 2013 / 14 : GPCRs. Br. J. Pharmacol. 170, 1459-1581. doi:10.1111/bph.12444/full

Andersen, S.L., Lyss, P.J., Dumont, N.L., Teicher, M.H., 1999. Enduring neurochemical effects of early maternal separation on limbic structures. Ann N Y Acad Sci 877, 756759.

Bateson, P., Barker, D., Clutton-Brock, T., Deb, D., D’Udine, B., Foley, R.A., Gluckman, P., Godfrey, K., Kirkwood, T., Lahr, M.M., McNamara, J., Metcalfe, N.B., Monaghan, P., Spencer, H.G., Sultan, S.E., 2004. Developmental plasticity and human health. Nature 430, 419-421. doi:10.1038/nature02725

Belyaev, D.K., 1979. Destabilizing selection as a factor in domestication. J. Hered. 70, 301308. doi:https://doi.org/10.1093/oxfordjournals.jhered.a109263

Ben-Shlomo, A., Melmed, S., 2010. Pituitary somatostatin receptor signaling. Trends Endocrinol. Metab. 21, 123-133. doi:10.1016/j.tem.2009.12.003.Pituitary

Benjannet, S., Rondeau, N., Day, R., Chrétien, M., Seidah, N.G., 1991. PC1 and PC2 are proprotein convertases capable of cleaving proopiomelanocortin at distinct pairs of basic residues. Proc. Natl. Acad. Sci. U. S. A. 88, 3564-8. doi:10.1073/pnas.88.9.3564

Bonfiglio, J.J., Inda, C., Refojo, D., Holsboer, F., Arzt, E., Silberstein, S., 2011. The Corticotropin-Releasing Hormone Network and the Hypothalamic-Pituitary-Adrenal Axis: Molecular and Cellular Mechanisms Involved. Neuroendocrinology 94, 12-20. doi: $10.1159 / 000328226$

Braastad, B., 1998. Effects of prenatal stress on behaviour of offspring of laboratory and farmed mammals. Appl. Anim. Behav. Sci. 61, 159-180.

Braastad, B., Osadchuk, L., Lund, G., Bakken, M., 1998. Effects of prenatal handling stress on adrenal weight and function and behaviour in novel situations in blue fox cubs (Alopex lagopus). Appl. Anim. Behav. Sci. 57, 157-169.

Buys, N., Dewil, E., Gonzales, E., Decuypere, E., 1998. Different CO2 levels during 
incubation interact with hatching time and ascites susceptibility in two broiler lines selected for different growth rate. Avian Pathol. 27, 605-612.

Campler, M., Jöngren, M., Jensen, P., 2009. Fearfulness in red junglefowl and domesticated White Leghorn chickens. Behav. Processes 81, 39-43.

Careghi, C., Tona, K., Onagbesan, O., Buyse, J., Decuypere, E., Bruggeman, V., 2005. The effects of the spread of hatch and interaction with delayed feed access after hatch on broiler performance until seven days of age. Poult. Sci. 84, 1314-1320.

Carneiro, M., Piorno, V., Rubin, C.J., Alves, J.M., Ferrand, N., Alves, P.C., Andersson, L., 2015. Candidate genes underlying heritable differences in reproductive seasonality between wild and domestic rabbits. Anim. Genet. 46, 418-425. doi:10.1111/age.12299

Carneiro, M., Rubin, C.J., Di Palma, F., Albert, F.W., Alfoldi, J., Barrio, A.M., Pielberg, G., Rafati, N., Sayyab, S., Turner-Maier, J., Younis, S., Afonso, S., Aken, B., Alves, J.M., Barrell, D., Bolet, G., Boucher, S., Burbano, H.A., Campos, R., Chang, J.L., Duranthon, V., Fontanesi, L., Garreau, H., Heiman, D., Johnson, J., Mage, R.G., Peng, Z., Queney, G., Rogel-Gaillard, C., Ruffier, M., Searle, S., Villafuerte, R., Xiong, A., Young, S., Forsberg-Nilsson, K., Good, J.M., Lander, E.S., Ferrand, N., Lindblad-Toh, K., Andersson, L., 2014. Rabbit genome analysis reveals a polygenic basis for phenotypic change during domestication. Science 345, 1074-1079. doi:10.1126/science.1253714

Carsia, R. V, 2014. Adrenals, in: Scanes, C.G. (Ed.), Sturkie's Avian Physiology. Elsevier, pp. 577-611.

Chrousos, G.P., 2009. Stress and disorders of the stress system. Nat. Rev. Endocrinol. 5, 374 381. doi:10.1038/nrendo.2009.106

Clutton-Brock, J., 1995. Origins of the dog: domestication and early history, in: The Domestic Dog: Its Evolution, Behaviour and Interactions with People. pp. 7-20.

Cockrem, J.F., 2007. Stress, corticosterone responses and avian personalities. J. Ornithol. 148, 169-178. doi:10.1007/s10336-007-0175-8

Coderre, L., Srivastava, A.K., Chiasson, J.L., 1991. Role of glucocorticoid in the regulation of glycogen metabolism in skeletal muscle. Am. J. Physiol. 260, E927-32.

Darwin, C., 1859. On the origin of species. John Murray, London, UK.

Darwin, C., 1868. The variation of animals and plants under domestication. John Murray, London, UK.

de Kloet, E.R., Joëls, M., Holsboer, F., 2005. Stress and the brain: from adaptation to disease. Nat. Rev. Neurosci. 6, 463-475. doi:10.1038/nrn1683

Decuypere, E., Bruggeman, V., 2005. Endocrine aspects of development: new challenges for the control of incubation process. Worlds. Poult. Sci. J. 61, 278-283. doi:10.1079/WPS200457

Depaolo, L. V., Shimonaka, M., Schwall, R.H., Ling, N., 1991. In vivo comparison of the follicle-stimulating hormone-suppressing activity of follistatin and inhibin in ovariectomized rats. Endocrinology 128, 668-674. doi:10.1210/endo-128-2-668

Draghici, S., Khatri, P., Tarca, A., Amin, K., Done, A., Voichita, C., Georgescu, C., Romero, R., 2007. A systems biology approach for pathway level analysis. Genome Res. 15371545. doi:10.1101/gr.6202607.1 
Ericsson, M., Fallahsharoudi, A., Bergquist, J., Kushnir, M.M., Jensen, P., 2014.

Domestication effects on behavioural and hormonal responses to acute stress in chickens. Physiol. Behav. 133, 161-169. doi:10.1016/j.physbeh.2014.05.024

Eto, M., 2009. Regulation of Cellular Protein Phosphatase-1 (PP1) by Phosphorylation of the CPI-17 Family, C-kinase-activated PP1 Inhibitors. J. Biol. Chem. 284, 35273-35277. doi:10.1074/jbc.R109.059972

Exton, J.H., 1979. Regulation of gluconeogenesis by glucocorticoids. Monogr. Endocrinol. $12,535-46$.

Fallahsharoudi, A., de Kock, N., Johnsson, M., Ubhayasekera, S.J.K.A., Bergquist, J., Wright, D., Jensen, P., 2015. Domestication Effects on Stress Induced Steroid Secretion and Adrenal Gene Expression in Chickens. Sci. Rep. 5, 15345. doi:10.1038/srep15345

Ferris, H.A., Shupnik, M.A., 2006. Mechanisms for pulsatile regulation of the gonadotropin subunit genes by GNRH1. Biol. Reprod. 74, 993-998.

doi:10.1095/biolreprod.105.049049

Fink, G., 2000. Feedback Systems, in: Fink, G. (Ed.), Encyclopedia of Stress, Volume 2. pp. 124-137.

Francis, D.D., Meaney, M.J., 1999. Maternal care and the development of stress responses. Curr. Opin. Neurobiol. 9, 128-34.

Fumihito, A., Miyake, T., Takada, M., Shingu, R., Endo, T., Gojobori, T., Kondo, N., Ohno, S., 1996. Monophyletic origin and unique dispersal patterns of domestic fowls. Proc. Natl. Acad. Sci. U. S. A. 93, 6792-6795. doi:10.1073/pnas.93.13.6792

Gibson, U.E., Heid, C.A., Williams, P.M., 1996. A novel method for real time quantitative RT-PCR. Genome Res. 6, 995-1001. doi:10.1101/gr.6.10.995

Groothuis, T.G.G., Müller, W., von Engelhardt, N., Carere, C., Eising, C., 2005. Maternal hormones as a tool to adjust offspring phenotype in avian species. Neurosci. Biobehav. Rev. 29, 329-352.

Gulevich, R.G., Oskina, I.N., Shikhevich, S.G., Fedorova, E. V., Trut, L.N., 2004. Effect of selection for behavior on pituitary-adrenal axis and proopiomelanocortin gene expression in silver foxes (Vulpes vulpes). Physiol. Behav. 82, 513-518. doi:10.1016/j.physbeh.2004.04.062

Hamburger, V., Hamilton, H., 1951. A series of normal stages in the development of the chick embryo. J. Morphol. 88, 49-92.

Hekman, J.P., 2017. Transcriptome analysis of the hypothalamic-pituitary-adrenal axis in the experimentally domesticated fox. University of Illinois at Urbana-Champaign.

Henriksen, R., Rettenbacher, S., Groothuis, T.G.G., 2011. Prenatal stress in birds: pathways, effects, function and perspectives. Neurosci. Biobehav. Rev. 35, 1484-1501.

Herman, J.P., Cullinan, W.E., 1997. Neurocircuitry of stress: Central control of the hypothalamo-pituitary-adrenocortical axis. Trends Neurosci. 20, 78-84. doi:10.1016/S0166-2236(96)10069-2

Herman, J.P., McKlveen, J.M., Ghosal, S., Kopp, B., Wulsin, A., Makinson, R., Scheimann, J., Myers, B., 2016. Regulation of the hypothalamic-pituitary-adrenocortical stress response. Compr. Physiol. 6, 603-621. doi:10.1002/cphy.c150015.Regulation 
Ideker, T., Galitski, T., Hood, L., 2001. A new approach to decoding life: systems biology. Annu. Rev. Genomics Hum. Genet. 2, 343-372. doi:10.1146/annurev.genom.2.1.343

Janczak, A.M., Braastad, B.O., Bakken, M., 2006. Behavioural effects of embryonic exposure to corticosterone in chickens. Appl. Anim. Behav. Sci. 96, 69-82. doi:10.1016/j.applanim.2005.04.020

Karthik, D., Ravikumar, S., 2011. Characterization of the brain proteome of rats with diabetes mellitus through two-dimensional electrophoresis and mass spectrometry. Brain Res. 1371, 171-179. doi:10.1016/j.brainres.2010.11.066

Keller-Wood, M., 2015. Hypothalamic-pituitary-adrenal axis-feedback control. Compr. Physiol. 5, 1161-1182. doi:10.1002/cphy.c140065

Kerje, S., Carlborg, O., Jacobsson, L., Schütz, K., Hartmann, C., Jensen, P., Andersson, L., 2003. The twofold difference in adult size between the red junglefowl and White Leghorn chickens is largely explained by a limited number of QTLs. Anim. Genet. 34, 264-274. doi:10.1046/j.1365-2052.2003.01000.x

Khatri, P., Sirota, M., Butte, A.J., 2012. Ten years of pathway analysis: Current approaches and outstanding challenges. PLoS Comput. Biol. 8, e1002375. doi:10.1371/journal.pcbi.1002375

Kim, G., Lee, Y., Jeong, E.Y., Jung, S., Son, H., Lee, D.H., Roh, G.S., Kang, S.S., Cho, G.J., Choi, W.S., Kim, H.J., 2010. Acute Stress Responsive RGS Proteins in the Mouse Brain. Mol. Cells 30, 161-165. doi:10.1007/s10059-010-0102-3

Kishimoto, T., Radulovic, J., Radulovic, M., Lin, C.R., Schrick, C., Hooshmand, F., Hermanson, O., Rosenfeld, M.G., Spiess, J., 2000. Deletion of crhr2 reveals an anxiolytic role for corticotropin-releasing hormone receptor-2. Nat. Genet. 24, 415-419. doi:10.1038/74271

Kreienkamp, H.J., Akgün, E., Baumeister, H., Meyerhof, W., Richter, D., 1999. Somatostatin receptor subtype 1 modulates basal inhibition of growth hormone release in somatotrophs. FEBS Lett. 462, 464-466. doi:10.1016/S0014-5793(99)01582-3

Künzl, C., Sachser, N., 1999. The behavioral endocrinology of domestication: A comparison between the domestic guinea pig (Cavia aperea f. porcellus) and its wild ancestor, the cavy (Cavia aperea). Horm. Behav. 35, 28-37. doi:10.1006/hbeh.1998.1493

Larson, G., Dobney, K., Albarella, U., Fang, M., Matisoo-Smith, E., Robins, J., Lowden, S., Finlayson, H., Brand, T., Willerslev, E., Rowley-Conwy, P., Andersson, L., Cooper, A., 2005. Worldwide Phylogeography of Wild Boar Reveals Multiple Centers of Pig Domestication. Science 307, 1618-1621. doi:10.1126/science.1106927

Liljedahl, L.E., Kolstad, N., Sørensen, P., Maijala, K., 1979. Scandinavian selection and crossbreeding experiment with laying hens, I. Background and general outline. Acta Agric. Scand. 29, 273-286.

Lin, D., Sugawara, T., Strauss, J., Clark, B., Stocco, D., Saenger, P., Rogol, A., Miller, W., 1995. Role of steroidogenic acute regulatory protein in adrenal and gonadal steroidogenesis. Science 267, 1828-1831. doi:10.1126/science.7892608

Liu, Q., Zhang, P., Lin, Z., Li, Q., Woods, A.S., Troncoso, J., Uhl, G.R., 2004. GBPI, a novel gastrointestinal- and brain-specific PP1-inhibitory protein, is activated by PKC and inactivated by PKA. Biochem. J. 377, 171-181. 
Maier, T., Güell, M., Serrano, L., 2009. Correlation of mRNA and protein in complex biological samples. FEBS Lett. 583, 3966-3973. doi:10.1016/j.febslet.2009.10.036

Malisch, J.L., Breuner, C.W., 2010. Steroid-binding proteins and free steroids in birds. Mol. Cell. Endocrinol. 316, 42-52. doi:10.1016/j.mce.2009.09.019

Martens, C., Bilodeau, S., Maira, M., Gauthier, Y., Drouin, J., 2005. Protein-protein interactions and transcriptional antagonism between the subfamily of NGFI-B/Nur77 orphan nuclear receptors and glucocorticoid receptor. Mol. Endocrinol. 19, 885-897. doi:10.1210/me.2004-0333

McEwen, B.S., 2007. Physiology and Neurobiology of Stress and Adaptation : Central Role of the Brain. Physiol. Rev. 87, 873-904. doi:10.1152/physrev.00041.2006.

McEwen, B.S., Wingfield, J.C., 2003. The concept of allostasis in biology and biomedicine. Horm. Behav. 43, 2-15. doi:10.1016/S0018-506X(02)00024-7

Munck, A., Guyre, P.M., Holbrook, N.J., 1984. Physiological functions of glucocorticoids in stress and their relation to pharmacological actions. Endocr. Rev. 5, 25-44. doi:10.1210/edrv-5-1-25

Myers, B., McKlveen, J.M., Herman, J.P., 2014. Glucocorticoid actions on synapses, circuits, and behavior: Implications for the energetics of stress. Front. Neuroendocrinol. 35, 180 196. doi:10.1016/j.yfrne.2013.12.003

Nakao, N., Ono, H., Yamamura, T., Anraku, T., Takagi, T., Higashi, K., Yasuo, S., Katou, Y., Kageyama, S., Uno, Y., Kasukawa, T., Iigo, M., Sharp, P.J., Iwasawa, A., Suzuki, Y., Sugano, S., Niimi, T., Mizutani, M., Namikawa, T., Ebihara, S., Ueda, H.R., Yoshimura, T., 2008. Thyrotrophin in the pars tuberalis triggers photoperiodic response. Nature 452, 317-322. doi:10.1038/nature06738

Nelson, R.J., 2005. An Introduction to Behavioral Endocrinology, Third Edit. ed. Sinauer Associates, Incorporated, Sunderland, MA.

Nicol, C.J., 2015. The behavioural biology of chickens. CABI.

Nielsen, B.L., Juul-Madsen, H.R., Steenfeldt, S., Kjaer, J.B., Sørensen, P., 2010. Feeding activity in groups of newly hatched broiler chicks: effects of strain and hatching time. Poult. Sci. 89, 1336-1344.

Nolan, T., Hands, R.E., Bustin, S. a, 2006. Quantification of mRNA using real-time RT-PCR. Nat. Protoc. 1, 1559-1582. doi:10.1038/nprot.2006.236

Nätt, D., Rubin, C.-J., Wright, D., Johnsson, M., Beltéky, J., Andersson, L., Jensen, P., 2012. Heritable genome-wide variation of gene expression and promoter methylation between wild and domesticated chickens. BMC Genomics 13, 59. doi:10.1186/1471-2164-13-59

Payne, A.H., Hales, D.B., 2004. Overview of steroidogenic enzymes in the pathway from cholesterol to active steroid hormones. Endocr. Rev. 25, 947-970. doi:10.1210/er.20030030

Plyusnina, I.Z., Solov'Eva, M.Y., Oskina, I.N., 2011. Effect of domestication on aggression in gray Norway rats. Behav. Genet. 41, 583-592. doi:10.1007/s10519-010-9429-y

Pozzoli, G., Bilezikjian, L.M., Perrin, M.H., Blount, A.L., Vale, W.W., 1996. Corticotropinreleasing factor $(\mathrm{CRF})$ and glucocorticoids modulate the expression of type $1 \mathrm{CRF}$ receptor messenger ribonucleic acid in rat anterior pituitary cell cultures. Endocrinology 
137, 65-71. doi:10.1210/endo.137.1.8536643

Preil, J., Müller, M.B., Gesing, A., Reul, J.M.H.M., Sillaber, I., van Gaalen, M.M., Landgrebe, J., Holsboer, F., Stenzel-Poore, M., Wurst, W., 2001. Regulation of the Hypothalamic-Pituitary-Adrenocortical System in Mice Deficient for CRH Receptors 1 and 2. Endocrinology 142, 4946-4955. doi:10.1210/endo.142.11.8507

Price, E.O., 1984. Behavioral Aspects of Animal Domestication. Q. Rev. Biol. 59, 1-32. doi:10.2307/2827868

Price, E.O., 1999. Behavioral development in animals undergoing domestication. Appl. Anim. Behav. Sci. 65, 245-271. doi:10.1016/S0168-1591(99)00087-8

Reis, L.H., Gama, L.T., Chaveiro Soares, M., 1997. Effects of Short Storage Conditions and Broiler Breeder Age on Hatchability, Hatching Time, and Chick Weights. Poult. Sci. 76, 1459-1466.

Robertson, D.M., Farnworth, P.G., Clarke, L., Jacobsen, J., Cahir, N.F., Burger, H.G., De Kretser, D.M., 1990. Effects of bovine $35 \mathrm{kDa}$ FSH-suppressing protein on FSH and LH in rat pituitary cells in vitro: Comparison with bovine $31 \mathrm{kDa}$ inhibin. J. Endocrinol. 124, 417-423.

Romeo, R.D., Tang, A.C., Sullivan, R.M., 2010. Early-life experiences: Enduring behavioral, neurological, and endocrinological consequences, in: Hormones, Brain and Behavior Online. pp. 1975-2006. doi:10.1016/B978-008088783-8.00062-0

Roseboom, T.J., van der Meulen, J.H.P., Ravelli, A.C.J., Osmond, C., Barker, D.J.P., Bleker, O.P., 2001. Effects of prenatal exposure to the Dutch famine on adult disease in later life: an overview. Mol. Cell. Endocrinol. 185, 93-98. doi:10.1016/S0303-7207(01)00721-3

Rubin, C.-J., Zody, M.C., Eriksson, J., Meadows, J.R.S., Sherwood, E., Webster, M.T., Jiang, L., Ingman, M., Sharpe, T., Ka, S., Hallböök, F., Besnier, F., Carlborg, Ö., Bed'hom, B., Tixier-Boichard, M., Jensen, P., Siegel, P., Lindblad-Toh, K., Andersson, L., 2010. Whole-genome resequencing reveals loci under selection during chicken domestication. Nature 464, 587-591. doi:10.1038/nature08832

Ruiz, J., Lunam, C.A., 2002. Effect of pre-incubation storage conditions on hatchability, chick weight at hatch and hatching time in broiler breeders. Br. Poult. Sci. 43, 374-383.

Sabban, E.L., Kvetňanský, R., 2001. Stress-triggered activation of gene expression in catecholaminergic systems: Dynamics of transcriptional events. Trends Neurosci. 24, 91-98. doi:10.1016/S0166-2236(00)01687-8

Sapolsky, R.M., Krey, L.C., McEwen, B.S., 1984. Glucocorticoid-sensitive hippocampal neurons are involved in terminating the adrenocortical stress response. Proc. Natl. Acad. Sci. U. S. A. 81, 6174-6177. doi:10.1073/pnas.81.19.6174

Sapolsky, R.M., Romero, L.M., Munck, A.U., 2000. How do glucocorticoids influence stress responses? Integrating permissive, suppressive, stimulatory, and preparative actions. Endocr. Rev. 21, 55-89.

Schena, M., Shalon, D., Davis, R.W., Brown, P.O., 1995. Quantitative Monitoring of Gene Expression Patterns with a Complementary DNA Microarray. Science. doi:10.1126/science.270.5235.467

Schulze, A., Downward, J., 2001. Navigating gene expression using microarrays - a 
technology review. Nat. Cell Biol. 3, E190-E195. doi:10.1038/35087138

Schütz, K.E., Forkman, B., Jensen, P., 2001. Domestication effects on foraging strategy, social behaviour and different fear responses: A comparison between the red junglefowl (Gallus gallus) and a modern layer strain. Appl. Anim. Behav. Sci. 74, 1-14. doi:10.1016/S0168-1591(01)00156-3

Schütz, K.E., Kerje, S., Jacobsson, L., Forkman, B., Carlborg, Ö., Andersson, L., Jensen, P., 2004. Major Growth QTLs in Fowl Are Related to Fearful Behavior: Possible Genetic Links between Fear Responses and Production Traits in a Red Junglefowl x White Leghorn Intercross. Behav. Genet. 34, 121-130. doi:10.1023/B:BEGE.0000009481.98336.fc

Shi, Y., Reddy, B., Manley, J.L., 2006. PP1 / PP2A Phosphatases Are Required for the Second Step of Pre-mRNA Splicing and Target Specific snRNP Proteins. Mol. Cell 23, 819-829. doi:10.1016/j.molcel.2006.07.022

Storey, A.A., Athens, J.S., Bryant, D., Carson, M., Emery, K., DeFrance, S., Higham, C., Huynen, L., Intoh, M., Jones, S., Kirch, P. V, Ladefoged, T., McCoy, P., Morales-Muñiz, A., Quiroz, D., Reitz, E., Robins, J., Walter, R., Matisoo-Smith, E., 2012. Investigating the Global Dispersal of Chickens in Prehistory Using Ancient Mitochondrial DNA Signatures. PLoS One 7, e39171. doi:10.1371/journal.pone.0039171

Tang, A.C., 2001. Neonatal Exposure to Novel Environment Enhances HippocampalDependent Memory Function During Infancy and Adulthood. Learn. Mem. 8, 257-264. doi:10.1101/lm.43101

Tapscott, S.J., 2005. The circuitry of a master switch: Myod and the regulation of skeletal muscle gene transcription. Development 132, 2685-2695. doi:10.1242/dev.01874

Tixier-Boichard, M.M., Bed'Hom, B., Rognon, X., 2011. Chicken domestication : From archeology to genomics. C. R. Biol. 334, 197-204. doi:10.1016/j.crvi.2010.12.012

Tona, K., Bamelis, F., De Ketelaere, B., Bruggeman, V., Moraes, V.M.B., Buyse, J., Onagbesan, O., Decuypere, E., 2003. Effects of egg storage time on spread of hatch, chick quality, and chick juvenile growth. Poult. Sci. 82, 736-741.

Tong, Q., Romanini, C., Exadaktylos, V., 2013. Embryonic development and the physiological factors that coordinate hatching in domestic chickens. Poult. Sci. 92, 620628.

Tremblay, J.J., Drouin, J., 1999. Egr-1 Is a Downstream Effector of GnRH and Synergizes by Direct Interaction with Ptx 1 and SF-1 To Enhance Luteinizing Hormone $\beta$ Gene Transcription 19, 2567-2576.

Trut, L., Oskina, I., Kharlamova, A., 2009. Animal evolution during domestication: the domesticated fox as a model. Bioessays 31, 349-360.

doi:10.1002/bies.200800070.Animal

Ulmer-Franco, A.M., Fasenko, G.M., O’Dea Christopher, E.E., 2010. Hatching egg characteristics, chick quality, and broiler performance at 2 breeder flock ages and from 3 egg weights. Poult. Sci. 89, 2735-2742.

van de Ven, L.J.F., van Wagenberg, A. V, Debonne, M., Decuypere, E., Kemp, B., van den Brand, H., 2011. Hatching system and time effects on broiler physiology and posthatch growth. Poult. Sci. 90, 1267-1275. 
Vandenborne, K., De Groef, B., Geelissen, S.M.E., Kühn, E.R., Darras, V.M., Van der Geyten, S., 2005. Corticosterone-induced negative feedback mechanisms within the hypothalamo-pituitary-adrenal axis of the chicken. J. Endocrinol. 185, 383-91. doi:10.1677/joe.1.05969

Vashchenko, G., Das, S., Moon, K.M., Rogalski, J.C., Taves, M.D., Soma, K.K., Van Petegem, F., Foster, L.J., Hammond, G.L., 2016. Identification of avian corticosteroidbinding globulin (SerpinA6) reveals the molecular basis of evolutionary adaptations in SerpinA6 structure and function as a steroid-binding protein. J. Biol. Chem. 291, 1130011312. doi:10.1074/jbc.M116.714378

Vieira, S., Almeida, J., Lima, A., 2005. Hatching distribution of eggs varying in weight and breeder age. Brazilian J. Poult. Sci. 7, 73-78.

Wang, Q.F., Farnworth, P.G., Findlay, J.K., Burger, H.G., 1990. Chronic inhibitory effect of follicle-stimulating hormone (FSH)-supressing protein or follistatin on activin and gonadotropin-releasing hormone-stimulated FSH synthesis and secretion in rat anterior pituitary cells. Endocrinology 127, 1385-1393.

Wang, Z., Wang, D.-Z., Pipes, G.C.T., Olson, E.N., 2003. Myocardin is a master regulator of smooth muscle gene expression. Proc. Natl. Acad. Sci. U. S. A. 100, 7129-7134. doi:10.1073/pnas.1232341100

Weaver, I.C.G., 2009. Shaping adult phenotypes through early life environments. Birth Defects Res. C. Embryo Today 87, 314-326. doi:10.1002/bdrc.20164

Weiler, U., Claus, R., Schnoebelen-Combes, S., Louveau, I., 1998. Influence of age and genotype on endocrine parameters and growth performance: a comparative study in Wild boars, Meishan and Large White boars. Livest. Prod. Sci. 54, 21-31. doi:10.1016/S03016226(97)00165-6

White, A., Gibson, S., 1998. ACTH precursors: Biological significance and clinical relevance. Clin. Endocrinol. (Oxf). 48, 251-255. doi:10.1046/j.1365-2265.1998.00451.x

Wilkanowska, A., Mazurowski, A., Mroczkowski, S., Kokoszyñski, D., 2014. Prolactin (PRL) and prolactin receptor (PRLR) genes and their role in poultry production traits. Folia Biol. doi:10.3409/fb62_1.1

Wilkins, A.S., Wrangham, R.W., Tecumseh Fitch, W., 2014. The "domestication syndrome" in mammals: A unified explanation based on neural crest cell behavior and genetics. Genetics 197, 795-808. doi:10.1534/genetics.114.165423

Wolfe, M.W., Call, G.B., 1999. Early growth response protein 1 binds to the luteinizing hormone-beta promoter and mediates gonadotropin-releasing hormone-stimulated gene expression. Mol Endocrinol 13, 752-763. doi:10.1210/mend.13.5.0276

Xiang, H., Gao, J., Yu, B., Zhou, H., Cai, D., Zhang, Y., Chen, X., Wang, X., Hofreiter, M., Zhao, X., 2014. Early Holocene chicken domestication in northern China. Proc. Natl. Acad. Sci. 111, 17564-17569. doi:10.1073/pnas.1411882111

Ying, S.Y., Becker, A., Swanson, G., Tan, P., Ling, N., Esch, F., Ueno, N., Shimasaki, S., Guillemin, R., 1987. Follistatin specifically inhibits pituitary follicle stimulating hormone release invitro. Biochem. Biophys. Res. Commun. 149, 133-139. doi:10.1016/0006-291X(87)91614-7

Zhang, T., Mulvaney, J.M., Roberson, M.S., 2001. Activation of mitogen-activated protein 
kinase phosphatase 2 by gonadotropin-releasing hormone. Mol Cell Endocrinol 172, 79 89. doi:S0303-7207(00)00378-6 [pii]

Zhang, T., Wolfe, M.W., Roberson, M.S., 2001. An Early Growth Response Protein (Egr) 1 cis-Element Is Required for Gonadotropin-releasing Hormone-induced Mitogenactivated Protein Kinase Phosphatase 2 Gene Expression. J. Biol. Chem. 276, 4560445613. doi:10.1074/jbc.M107075200

Zuidhof, M.J., Schneider, B.L., Carney, V.L., Korver, D.R., Robinson, F.E., 2014. Growth, efficiency, and yield of commercial broilers from 1957, 1978, and 2005. Poult. Sci. 93, 2970-82. doi:10.3382/ps.2014-04291 


\section{Papers}

The papers associated with this thesis have been removed for copyright reasons. For more details about these see:

http:// urn.kb.se/ resolve?urn=urn:nbn:se:liu:diva-143053 